\title{
Recenzje
}

DOI 10.14746/ssp.2018.2.12

\section{Грант Микаелян, Теневая экономика в Армении, Институт Кавказа, Ереван 2016, ss. 188.}

Problem transformacji państw postradzieckich wciąż jest przedmiotem pogłębionych badań politologicznych. Po załamaniu się wiary zarówno w „koniec historii", jak i możliwości trwałej demokratyzacji całego obszaru byłego Związku Radzieckiego, przyszedł czas poszukiwania odpowiedzi na źródła względnej stabilności obecnej „szarej strefy” demokracji, która wydaje się stanowić specyficzną formę reżimu politycznego właściwą temu obszarowi. Oligarchizacja życia publicznego, zawłaszczanie instytucji państwowych, dysponowanie majątkiem publicznym jak własnym, nepotyzm, korupcja, to zjawiska właściwe takim państwom jak Mołdawia, Armenia, Rosja, Uzbekistan czy Tadżykistan. Te dysfunkcjonalne cechy i mechanizmy, świadczące o słabości państwa, paradoksalnie stały się na obszarze postradzieckim swoistym modus vivendi ich życia politycznego i funkcjonowania społeczeństw. Zjawiska nieformalne dają ich uczestnikom duży zakres swobody, zaś doraźne korzyści mogą rekompensować słabość instytucji państwa i polityki publicznej (np. w sferze rynku pracy) (Misztal, 2000, s. 8). Z tego powodu coraz częściej do badań nad reżimami politycznymi tego obszaru używa się paradygmatu neopatrymonialnego (Hale, 2015; Czachor, 2015).

Istotnym elementem postradzieckich transformujących się społeczeństw stała się szara strefa gospodarcza. Nie tylko jako źródło dochodu dla wielu obywateli, lecz także zorganizowana działalność, sprawne funkcjonowanie grup, które wpływają na życie polityczne oraz prawodawstwo. W tym kontekście za interesujący należy uznać przypadek Armenii, najmniejszej i najuboższej republiki Kaukazu Południowego, w której stosunkowo wąskie grupy klanowe od lat zawłaszczają przestrzeń publiczną i decydują o polityce państwa. Można twierdzić, uwzględniając lokalną specyfikę, że w Armenii i formule predatory state jak w soczewce skupiają się problemy obecne w większości państw byłego Związku Radzieckiego.

W związku z powyższym, za godną odnotowania należy uznać wydaną w języku rosyjskim książkę Szara strefa gospodarcza Armenii, która stanowi syntetyczny przegląd procesu kształtowania się i funkcjonowania mechanizmów 
gospodarczo-politycznych. Recenzowana publikacja została napisana przez ormiańskiego politologa Granta Mikaeliana, współpracownika uznanego erywańskiego think-tanku Instytut Kaukazu. Monografia w pewnym stopniu rozwija ustalenia poczynione w pracy zbiorowej War, Business and Politics: Informal Networks and Formal Institutions in Armenia (Iskandaryan, Mikaelian, Minasyan, 2016). Za cel autor postawił sobie przedstawić zjawisko szarej strefy gospodarczej w Armenii w interdyscyplinarnym kontekście socjologicznym, politologicznym i ekonomicznym (s. 11). Z zadania tego wywiązał się prawidłowo. Wykorzystano dostępną literaturę, niektóre źródła badacz po raz pierwszy wprowadza do obrotu naukowego, ponadto wykorzystano metody jakościowe, w tym wywiady pogłębione.

Treść recenzowanej pracy podzielona została na sześć rozdziałów i zakończenie. Pierwszy rozdział, Społeczne dyskursy i szara strefa, unaocznia, że funkcjonowanie szarej strefy gospodarczej ma istotne znaczenie dla ekonomiki Armenii, ale także zajmuje, wraz ze zjawiskiem korupcji, kluczowy element dyskursu społeczeństwa ormiańskiego. Wskazano, że choć zarówno obywatele, jak i elity władzy, postrzegają te kwestie jako patologie, nie podejmują faktycznych, wychodzących poza deklaracje, działań naprawczych. W powszechnym myśleniu mające miejsce w Armenii istotne dysproporcje w poziomie życia obywateli są skutkiem dominacji określonych grup klanowych w polityce, co umożliwia im nieuprawnione wykorzystywanie zasobów publicznych, prowadzenie rozmaitych niezgodnych z prawem działań na styku instytucji państwa i sektora biznesowego. G. Mikaelian podnosi także, że rozmiary szarej strefy są tak duże, że jej istnienie obiektywnie przynosi rozwiązanie szeregu problemów życia społecznego, z którymi instytucje publiczne nie są w stanie sobie poradzić (s. 14-15). Tym samym nieformalne zjawiska nabrały w tym państwie systemowego charakteru i będą bardzo trudne do wyeliminowania. Pogląd ten autor konfrontuje $\mathrm{z}$ danymi EBOR, według których wyobrażenia o korupcji w Armenii są zawyżone, i pod tym względem państwo to wypada lepiej niż inne republiki postradzieckie (s. 18).

Drugi rozdział, Konceptualne ramy pojęcia szarej strefy gospodarczej, rozpoczynają ogólne rozważania nad zjawiskiem szarej strefy i jej klasyfikacja. Autor wskazuje, że w powszechnej świadomości Ormian likwidacja tego zjawiska uważana jest za panaceum na wszystkie problemy w społeczno-ekonomicznym rozwoju państwa i warunek jej przyspieszonego rozwoju. Brak trwałych działań skierowanych przeciwko szarej strefie autor uzasadnia wspomnianymi wyżej doraźnymi korzyściami, które pozwalają instytucjom publicznym odkładać w czasie reformy i podnoszenie ich efektywności. Wskazuje także na problem faktycznej dominacji instytucji nieformalnych nad formalnymi, co praktycznie sprawia, że przestrzeń publiczna funkcjonuje pod dyktando najpotężniejszych aktorów szarej strefy (s. 41-43).

Kolejny rozdział pracy Geneza szarej strefy w Armenii - nieoficjalny handel $w$ ZSRR poświęcony został omówieniu okoliczności kształtowania się szarej strefy w okresie istnienia Związku Radzieckiego i jej ówczesnym formom. Pod- 
kreślono, że szara strefa kształtowała się nie tylko za milczącym przyzwoleniem, ale także udziałem działaczy partyjnych. Szczególnie rozwinęło się to zjawisko w takich republikach, jak Armeńska SRR, gdzie więzy klanowe przetrwały najtrudniejsze czasy bolszewickiego terroru i rozkwitty w epoce Leonida Breżniewa. Do początku pierestrojki w połowie lat 80 . szara strefa wytwarzała do $21 \%$ republikańskiego PKB. Były to jednak wskaźniki nieco niższe niż w przypadku sąsiedniej Gruzińskiej SRR czy Azerbejdżańskiej SRR (s. 67).

Czwarty rozdział Transformacja gospodarki w czasie pierestrojki i przedsiębiorczość we wspótczesnej Armenii porusza zagadnienie ,wyjścia na powierzchnię" szarej strefy, czyli oficjalne umożliwienie indywidualnej działalności gospodarczej rozkwit wolnego rynku. Proces ten zdominowały uprzywilejowane grupy dawnej partyjnej nomenklatury oraz nowi wpływowi uczestnicy życia publicznego, których kariera związana była z wojną w Górskim Karabachu. Autor opisuje, choć bez odwoływania się do personaliów, w jaki sposób ormiańscy polowi dowódcy po opuszczeniu linii frontu odnajdywali się w działalności polityczno-biznesowej. Zrozumienie tego fenomenu jest kluczem nie tylko do poznania współczesnej sceny politycznej Armenii, specyfiki jej świata biznesu, ale także przyczyn bierności władz względem zjawisk nieformalnych.

Rozdział piąty, zatytułowany Państwo, przedsiębiorcy i szara strefa gospodarcza po 2000 r. dotyczy okresu, gdy scena polityczna Armenii przeszła proces petryfikacji, poszczególne grupy interesu wyznaczyły swoje obszary działania, zaś władze oficjalnie rozpoczęły szereg programów skierowanych na walkę z korupcją i zjawiskami nieformalnymi (pierwszy z nich formalnie realizowano w latach 2000-2003). Ukształtowany wówczas konsensus elit posłużył zawłaszczaniu instytucji publicznych i rozwojowi działalności biznesowej. Przynależność do danej grupy, klanu, lojalność wobec prezydenta były kluczowymi kryteriami obsadzania urzędów i przepustką do czerpania korzyści w duchu predatory state (s. 108). G. Mikaelian wskazuje, że od 2003 roku więcej biznesmenów z szarej strefy uzyskiwało mandaty parlamentarne, co zaczęło upodabniać Armenię do innych państw postradzieckich, gdzie oligarchowie aktywnie uczestniczyli w życiu politycznym. Pęd oligarchów do parlamentu autor thumaczy też próbą zabezpieczenia się przez nich przed ewentualnymi wrogimi działaniami ze strony innych koterii skupionych wokół prezydenta oraz chęcią wpływania w większym stopniu na sytuację w Armenii (s. 110). Rozdział zawiera także analizę współczesnej ormiańskiej elity polityczno-biznesowej, choć bezpośrednio nie wymieniono nazwisk (co, jak informuje autor, było celowym zabiegiem). Zjawiska po kryzysie gospodarczym, który miał miejsce w 2008 roku, badacz nazywa feudalizacją, czyli wzrostem kontroli państwa nad szarą strefą i dominującymi nad nią oligarchami. Utrzymano pewien status quo, choć zakres samodzielności biznesmenów zmalał (s. 114-115). Autor wskazuje, że współcześnie oligarchowie określili swoje strefy wpływów, nie dążą do rozbudowy swoich „księstw udzielnych" i oczekują od instytucji publicznych regulacji, które pozwoliłyby utrzymać stan posiadania (s. 119). 
Następny rozdział Empiryczne dowody rozmiaru i dynamiki szarej strefy gospodarczej w Armenii zawiera analizę szeregu danych statystycznych dotyczących szarej strefy oraz korupcji zarówno w kontekście dużego biznesu, jak i małych i średnich przedsiębiorstw. Autor wnioskuje, że nieformalne porozumienia duże przedsiębiorstwa zawierają z wiodącymi politykami, podczas gdy mniejsi biznesmeni wstępują $\mathrm{w}$ niejawne porozumienia $\mathrm{z}$ przedstawicielami urzędów skarbowych i różnych inspekcji. Ogółem jednak udział szarej strefy w PKB Armenii jest obecnie szacowany na poziomie ponad $30 \%$ względem około $60 \%$ na początku lat 90. (s. 158).

W Zakończeniu autor podsumowuje przesłanki sprawiające, że szara strefa w Armenii wciąż ma systemowy charakter. Wśród nich: względnie młodą państwowość Armenii, słabość instytucji publicznych, niski poziom życia obywateli, wysoki poziom bezrobocia, znaczny poziom dysproporcji społecznych (wyrażanych m.in. w postaci indeksu Giniego). G. Mikaelian wymienia także potencjalne narzędzia walki z szarą strefą: dotowanie najbiedniejszych regionów, obniżenie podatków, ulgi dla małego i średniego biznesu, działania na rzecz wzrostu zaufania obywateli do instytucji publicznych oraz świadomości obywatelskiej (s. 178-180).

Podsumowując, recenzowana książka jest cenną pozycją dla badaczy procesów transformacji republik postradzieckich, specyfiki ich rozwoju społecznogospodarczego oraz naukowców zajmujących się zjawiskami nieformalnymi w przestrzeni publicznej państw znajdujących się w fazie demokratyzacji.

\section{Bibliografia}

Czachor R. (2015), Postradzieckie rezimy polityczne w perspektywie neopatrymonialnej. Wstęp do badań, Instytut Polsko-Rosyjski, Wrocław.

Hale H. E. (2015), Patronal Politics. Eurasian Dynamics in Comparative Perspective, Cambridge University Press, Cambridge.

Iskandaryan A., Mikaelian H., Minasyan S. (2016), War, Business and Politics: Informal Networks and Formal Institutions in Armenia, Caucasus Institute, Yerevan.

Misztal B. (2000), Informality: Social Theory and Contemporary Practice, Routledge, New York.

Rafat CZACHOR

Uczelnia Jana Wyżykowskiego 